\title{
Development Of Module Teaching Materials With Predict - Oberve - Explain (POE) Models Based On Gamification On Triangle Materials
}

\author{
Nurhaliza, Laila Maharani , Rizki Wahyu Yunian Putra \\ Fakultas Tarbiyah dan Keguruan UIN Raden Intan Bandar Lampung \\ E-mail : Nnurhaliza16@gmail.com
}

\begin{abstract}
The learning process is certainly not only limited to the increase in students' knowledge or cognitive abilities, but also includes better behavior and thinking abilities, and no less important is how the learning process makes students able to solve problems faced both in learning in school, as well as in the daily life they experience. The development of ICT technology has had an impact on the development of the games industry, which makes educators more creative in designing their learning processes. Some game designers have studied deeper about psychology or other sciences that study human motivation and behavior. The method in this research is research and development (R\&D) with the ADDIE development model. Data collection instruments used were questionnaires given to material experts and media experts to find out the feasibility of the product, and given to students and educators, to find out the attractiveness of the products that have been developed as well as pretest and posttest test instruments. Based on the analysis of data obtained from material experts and media experts, it was stated that the teaching materials developed were feasible to be used, and the analysis of the data obtained from students and educators stated that the teaching materials developed were very interesting. The results of the analysis of the effectiveness of class data applied teaching material obtained and calculated with the formula Effect Size obtained is $E_{s}=0,34$. E_s calculation results are then interpreted to see the effectiveness criteria, the magnitude of $E_{s}=0,34$, which is in the range of $0,20<E_{s} \leq 0,80$, based on the category determined by the level of effectiveness of the magnitude of the class $E_{s}$ applied to learning using module teaching materials with the Predict - Oberve learning model - Explain (POE) based on gamification on the material of SMP triangles is categorized quite effective with a classification classified as medium.
\end{abstract}

Keywords: Module Teaching Material with Gamification-Based Predict - Oberve - Explain (POE) Model

\section{INTRODUCTION}

Education is a reciprocal process between educators and students, involving various other educational factors held to achieve educational goals, with always based on certain values, where those values are referred to as the basis of education. (Hamdani Hamid, 2013) Education functions to develop capabilities and shape the character and civilization of a dignified nation in the context of intellectual life of the nation. The curriculum has an important role in the education process. (Ismail Suardi Wekke, Ridha Windi Astuti, 2017) The curriculum is a set of plans and arrangements regarding the objectives, content and learning materials as well as the ways used as guidelines for organizing learning activities to achieve certain educational goals. (Imas Kurinasih and 
Berlian Sani, 2014). Achieving educational goals outlined in the learning process where students learn. Learning activities begin with the exploration of concepts, namely providing opportunities for students to express ideas in accordance with the initial knowledge they have. Students are given the opportunity to find their own answers to the problems given and other matters relating to observation and experience. Education is very important for every individual both for personal interests and in his position as a citizen. Education functions to develop capabilities and shape the dignified character and civilization of the nation in the context of developing the intellectual life of the nation, aiming at developing the potential of students to become human beings who believe in and fear God Almighty, have noble, healthy, knowledgeable, skilled, creative, independent, and become democratic and responsible citizens (Bambang Sri Anggoro, 2015).

Activities or activities carried out during learning are very influential on student achievement. Learning that is dominated by the teacher will cause boredom for students because student activities are limited to listening and taking notes. So that learning activities can have an influence on improving learning achievement, learning designs or scenarios created by teachers must be oriented towards student activities. Activities carried out by educators during learning are very influential on student learning outcomes. Learning that is dominated by educators will cause boredom for students because the activities of students are limited to listening and taking notes. Learning activities can have an influence on improving learning outcomes, designs or learning scenarios created by educators must be oriented towards student activities. This is in accordance with the curriculum applied in schools, namely the 2013 curriculum, where learning includes a component of observing, asking, trying, processing, presenting, concluding and creating. Therefore, the learning activities that take place need the right model or method. The learning model used must be interesting and able to make students play an active role in it. If the learning model that is used is interesting, then students see mathematics as an interesting subject and not boring to learn so that it has a great desire to learn.

The learning process is of course not only limited to increasing students' knowledge or cognitive abilities, but also includes better behavior and thinking abilities, and no less important is how the learning process makes students able to solve problems faced both in learning in school, and in the daily life they experience. Students to be accustomed to solving problems can be accustomed to in the learning process, it is the task of educators who help students to achieve this, by making the teaching and learning process more active, enjoyable, and arouse students' thinking abilities and skilled skills. Quoting from Hamzah B. Uno and Nurdin Mohamad, creative learning is one of the strategies that encourages students to be more free to learn the meaning they learn. Creative learning is also very important in the context of the formation of a creative generation, which is able to produce something for the benefit of himself and others. According to Hamzah B Uno (2012) Creative is also intended for teachers to create diverse learning activities so that it meets various levels of student ability.

Creative learning can also help students have the skills used in doing the things that they need. One alternative learning model that involves active students is the POE (Predict-Observe-Explain) model. This is because the POE learning model is a learning model in the order of the process of building knowledge by first predicting solutions to problems, then conducting experiments to prove predictions, and finally explaining the 
results of experiments. This learning model was first introduced by White and Gunstone in 1992. (Matthew Kearney and David F. Treagust, 2001)

The POE model provides the opportunity for students to be able to construct their own knowledge, observe observations of phenomena that occur and be skilled at communicating their ideas and discussion results. The scientific process skills of students can develop and be able to be applied in real life everyday.

Some research findings found that the use of the POE model can be used by educators to provide a deep understanding of learning design activities and strategies that the learning start starts from the viewpoint of learners rather than educators. The POE model has the influence to develop curriculum, learning strategies, teacher development, assessment of students' understanding and level of student learning outcomes. Other research results also state that the POE model has a positive effect on students' understanding of abstract material. The results of his study stated that by using the POE model the level of success of students is better than conventional learning. In addition, the results of the study also stated that the POE model had a significant influence on the increase in student knowledge in the field of science material.

This gives an illustration that the POE model is a good model to be applied to mathematics learning in the hope that students will get used to daring to try, trying to be able to understand a concept being learned. The solution of these problems is that at least the educator is able to create a learning atmosphere that can stimulate students to actively learn. Besides that, teaching material is one of the needs that must be provided by students so that they can be able to explore the ability to understand concepts.

The criteria used in the selection of media or teaching materials that support the content of learning materials and the ease of obtaining them. The appropriate media is not yet available, the teacher tries to develop it himself. The media include visual-based media which include images, graphic charts, transparencies, and slides, audio-visual media (video and audio-tape), and computer-based media (computer and interactive video). (Azhar Arsyad, 2013)

In accordance with the learning objectives of mathematics that one of the objectives of learning mathematics is that students can understand mathematical concepts. Understanding mathematical concepts in learning, students are required to construct their knowledge and understanding through the process of analysis, synthesis, filtering and using the concepts learned to develop problem solving problems so learning will feel more meaningful. Providing good results requires a high understanding of concepts, so teachers must be able to apply an atmosphere that can make students enthusiastic about the existing problems, so they are able to try to solve the problem. The use of teaching materials that direct students to the understanding of concepts is very supportive to help carry out the learning process in order to expedite the learning process, and the use of teaching materials can help students to obtain additional information that is not necessarily easily obtained quickly from other places.

Teaching materials that are in accordance with the development of concept understanding in the form of textbooks can be well developed so that it guides students in constructing facts, concepts, principles, or mathematical procedures in accordance with the material being studied. The learning process and the impact of the use of developed teaching materials certainly have an important role for teachers. The impact 
of its use, among others: 1) see how teaching materials can work to achieve learning objectives in the activities of students, 2) how students think in the learning process then the impact will be obtained from the use of teaching materials that will determine the quality of teaching materials and 3 ) how appropriate learning routes should be in order to achieve the learning objectives formulated.

Teaching material that is suitable with the material to be delivered is a supporting tool to foster students' learning interest. Most students are not interested in teaching materials available at school because there are still many using textbooks or guidebooks. Working on questions and exercises students only use learning material books or textbooks for guidance, while students' responses in working on textbooks are lacking in literacy because in essence students ask more questions than digesting the questions first. So the basic concept is already lacking, literacy is low and awareness of learning is also low. The new innovations in teaching materials to be conveyed to students is the right step to foster students 'learning interest, because not to make learning monotonous and can provoke students' creativity and interactions that are needed to improve learning. Innovations in teaching materials made by educators will change the paradigm of students in mathematics students who seem difficult.

The development of mathematics learning teaching materials in this triangle material applies the principles of learning design presented in the form of a model that directs researchers to design learning that is used as a guide in organizing learning in order to achieve effective, efficient, attractive and humane learning so that researchers are interested in developing teaching materials to minimize the difficulties experienced by students by understanding a Triangle material concepts by applying POE models with the help of teaching materials in the form of Gamification so as to reduce difficulties in learning mathematics. In connection with the research conducted, researchers expect a change in learning tools in order to improve mathematics learning. The facilities are module teaching materials with Gamification-based POE models on triangular material which will later become a guide when learning. Based on the description above, the author seeks to overcome the existing problems by conducting research with the title, namely the development of module teaching materials with predict-oberve-explain (POE) models based on gamification on triangular material.

Based on the problems raised, the objectives to be achieved in this study are to find out: (1) How to develop instructional materials in the form of modules using Gamification-Based POE Model on Triangle Material ?, (2) How to develop teaching materials in the form of modules using the Gamification-Based POE Model on Material The triangle developed is feasible to be implemented in junior high school learning and is interesting for students ?, (3) How is the effectiveness of learning using teaching materials in the form of modules using POE Model Based on Gamification on Triangle Material?

\section{RESEARCH METHOD}

This type of research is carried out by research and development methods (Research and Development). Research and Development is a research method produced to produce products. This study aims to develop a particular product and test the 
effectiveness of the product. The product produced from this research is teaching material in the form of modules using Gamification Based POE Model on Triangle Material. This developmental research used ADDIE research model. The selection of this model is based on the consideration that this model is easy to understand, besides that this model is developed systematically and rests on the theoretical foundation of the developed learning design. This model is programmed in a systematic way in an effort to solve learning problems related to learning media that are appropriate to the needs and characteristics of students. The ADDIE research stages are: Analysis, Design, Development, Implementation, Evaluations.

The research location was determined purposively or deliberately chosen according to the objectives and the difficulties in understanding the concepts in mathematics learning, as well as the value of the students being educated at schools, medium and high, which still lacks the experience of lack of interest in learning and difficulties in understanding concepts in mathematics learning, as well as the value of the school which is still low so that the value of the school is still very low so the value of the material is still used. This is SMP Negeri 11 Bandar Lampung. The technique of collecting the material intended in this research is to use interviews, questions and questionnaires (questionnaire) as well as documentation.

Implementation of research and development (R\&D), researchers use two types of data collected, namely: (1) Qualitative data, i.e. it can simply be called data from category results (coding) for content of data in the form of words or can be defined as data not numbers but framed and has the characteristic of not being able to do mathematical operations such as addition, subtraction, multiplication and division. Qualitative data in this study are in the form of learning instructional material categories in logarithmic material based on a questionnaire that has been filled out by material experts, and students. (2) Quantitative data, that is data in the form of numbers in the true sense, so various mathematical operations can be performed on the data quantitative. Quantitative data in this study were in the form of research scores for each evaluation criteria point in the questionnaire of teaching materials filled by material experts, junior high school teachers, and students as users. Rating point criteria are changed to a Likert scale score.

\section{RESULTS AND DISCUSSION}

Discussions in this study include:

A. Product Development Results

The development process that researchers carried out to produce module teaching materials with predict - oberve - explain (POE) models based on Gamification concepts on the Triangle material using ADDIE models namely 1) Analysis, 2) Design, 3) Development, 4) Implementation, and 5) Evaluation. Based on the product produced, the researcher can find out the feasibility and effectiveness of learning using module teaching materials with a predict - oberve - explain (POE) model based on Gamification concepts on Triangle material.

B. Product Characteristics

The results of the development carried out by the researchers produced a product that is a teaching material module with a predict - oberve - explain (POE) model based on the concept of Gamification on Triangle material which has the following characteristics: 
1) Basic competency-based teaching materials that are in accordance with the 2013 curriculum which are in accordance with Ministry of Education and Culture Regulation no 24 of 2016.

2) Teaching material developed requires students to understand the concept by filling in the parts of the concept that have not been filled in accordance with the understanding of the previous material.

3) Existing questions are given based on the students' ability from low to difficult questions.

4) The design is designed to be attractive, dynamic and makes it easier for students that the competencies being studied can be mastered easily, simply and meaningfully

5) Appearance makes student interest in learning.

\section{Effectiveness of Learning Using Products that are developed}

The effectiveness of teaching materials is measured using analysis of pretest and posttest student learning outcomes at the end of the learning activities that have been carried out. Written test is taken after learning activities using module teaching materials with predict - oberve - explain (POE) models based on the concept of Gamification on the material Triangle completed. The effectiveness of a learning is achieved when learning material can be absorbed perfectly by students. The learning process occurs a good interaction between students and educators so that learning becomes active and more meaningful. Awareness of the importance of social interaction gave birth to some in-depth studies, how should the teaching and learning process be applied in accordance with the plans that have been prepared. These problems are basically inseparable from the effectiveness factor in learning itself. The effectiveness of learning is part of the change in the learning process that has been prepared so that it provides appropriate and appropriate results in accordance with a plan that is designed to achieve all objectives in learning. Agree with Mulyasa stated that "effectiveness is related to the implementation of all the main tasks, the achievement of objectives, timeliness and the active participation of its members". (Naning Sutriningsih, 2015)

The issue of effectiveness is usually closely related to the comparison between the level of achievement of objectives with a plan that has been prepared previously, or the comparison of real results with planned results. Sutikno stated that "learning effectiveness is a learning that allows students to interact actively, fun, and can achieve the learning objectives as expected. The goals of mathematics learning include cognitive and effective goals. Cognitive goals in the form of students' ability to master mathematical concepts that can be seen from the results of tests given, while the effective aspects are seen from attitudes when learning takes place ". (Fitri Sri Sugesti, 2016).

The importance of effectiveness in the learning process will have an impact on learning outcomes if in the learning process teachers find ways and always try to get students actively involved in learning with high learning time presentations, positive student responses to learning. The terms of a learning are said to be effective if the main requirements of effectiveness are fulfilled, namely in a learning process the percentage of students' learning time in KBM is related to the implementation of the planned learning plan, adapted to activities that make the learning process interesting, enjoyable and in accordance with the specified learning time so implementation can go according to the plan drawn up in the learning plan. 
Achieving the desired goals, needs to be strived for students to be motivated to learn independently, so they can follow changes in life patterns and can establish cooperation in harmony of life, where in the process of good learning interactions in effective learning as all efforts to help students to be able to provide the expected test results. Teachers must be able to create an effective learning process so that students actively participate in learning activities. An effective learning process is able to provide space for students in their own learning students are guided and directed to the understanding of students in finding concepts so that learning outcomes are achieved optimally.

The use of gamification to increase motivation and interest is an important development in learning. Malone and Lepper in Meyhart (2016) analyzed the positive impact of game elements in the context of learning. Some current research also shows that an approach with gamification can improve student learning environments and practice applications for customers. The potential of gamification for learning and gaining knowledge in business contexts has received little attention to date. But it can also be seen from other literature studies, some studies say the effect of gamification does not last long, but it can still be a new thing to learn. (Muhammad Takdir, 2017).

The effectiveness of module teaching materials with predict - oberve - explain (POE) models based on Gamification concepts on Triangle material is shown by the Effect Size analysis obtained, $E_{S}=0,47$. The results of the calculation of $E_{S}$ are further interpreted to see the effectiveness criteria of the magnitude of $E_{s}=0,34$, which is in the range of $0,20<E_{s} \leq 0,80$, based on the category determined by the level of effectiveness of the magnitude of the class E_s applied to learning using module teaching materials with the predict - oberve - model explain (POE) based on the concept of Gamification in the material Triangle is quite effective with a classification classified as medium.

\section{CONCLUSION}

Based on the discussion and results of development in the process developed in research and development (Research and Development). So it can be concluded that in the development of module teaching materials with predict - oberve - explain (POE) models based on Gamification concepts on Segitigalayak material and effective in learning, the conclusions that can be drawn from this study are as follows:

Development of module teaching materials with predict - oberve - explain (POE) models based on Gamification concepts on Triangle material using ADDIE research and development which has 5 stages including: Analysis, Analysis, Design, Development ), Implementation (Implementation) and Evaluation (Evaluation). This stage is supported by Microsoft Word 2010 and Adobe PhotoShop. The resulting product is a module teaching material with a predict - oberve - explain (POE) model based on the Gamification concept on Triangle material.

Student responses to the appropriateness and attractiveness of module teaching materials with a predict - oberve - explain (POE) model based on the concept of Gamification on the resulting Triangle material are feasible to use and interesting for students. In the student response test that was tested on a small class tryout obtained an average value of 3.28 with a very feasible and very interesting category that was carried out on students of SMP N 11 Bandar Lampung thus developing module teaching 
materials with the predict model - Oberve - explain (POE) based on the concept of Gamification on the material Triangle is feasible and very interesting for students.

The effectiveness of learning using module teaching materials with predict - oberve explain (POE) models based on the concept of Gamification on the material Triangle calculated with the Effect Size analysis formula obtained is $E_{s}=0,34$. The results of the calculation of $E_{s}$ are further interpreted to see the effectiveness criteria of the magnitude of $E_{S}=0,34$, which is in the range of $0,20<E_{S} \leq 0,80$, based on the category determined effectiveness level of the magnitude of the class $E_{s}$ applied in learning using module teaching modules with predict - oberve - explain models (POE) based on the concept of Gamification in the material Triangle is quite effective with a classification classified as medium.

\section{REFERENCES}

Adebayo, F \& Theodora B. "Generative and Predict-Observe-Explain (POE) instructional Strategies: Toward Enchancing Basic Science Practical Skill of Lower Primary School Pupils". Internasional Journal of Elementary Education. 2015; Vol 4 No. (4), halaman: 86-92.

Azhar Arsyad. Media Pembelajaran. Jakarta: PT Grafindo Persada. 2013: 101.

Bambang S. A. "Pengembangan Modul Matematika Dengan Strategi Problem Solvin Guntuk Mengukur Tingkat emampuan Berpikir Kreatif Matematis Siswa, ”AlJabar: Jurnal Pendidikan Matematika. 2015; vol 6, no. 2, halaman: 122.

Hamndani Hamid. Pengembangan Sistem Pendidikan di Indonesia. Bandung: Pustaka Setia. 2013: 34 .

Hamzah B. Uno dan Nurdin Mohamad. Belajar dengan Pendekatan PAILKEM. Cet. Ke2.Jakarta: Bumi Aksara, 2012:12.

Imas Kurinasih dan Berlian Sani.Implementasi Kurikulum 2013 Konsep dan Penerapan. Surabaya: Kata Pena. 2014: 3.

Ismail Suardi Wekke, Ridha Windi Astuti.Kurikulum 2013 di Madrasah Ibtidaiyah: Implementasi “. Tadris: :Jurnal Keguruan dan Ilmu Tarbiyah. 2017: Vol.2 No.1,halaman: 33.

Matthew Kearney and David F. (2001). Treagust, Constructivism As A Referent in The Design and Development of A Computer Program UsingInteractive Digital Video to Enhance Learning in Physics, Electronic Australian Journal of Educational Technology. 2001. vol 17 (1), halaman: 64-79.

Muhammad Takdir. Kepomath Go Penerapan Konsep Gamifikasi dalam Pembelajaran Matematika dalam Meningkatkan Motivasi Belajar Matematika Siswa. Jurnal Penelitian Pendidikan Insani. 2017. Vol 20, No 1. halaman: 1 - 6.

Sutriningsih, Naning. Pembelajaran Lingkaran Melalui Strategi Pemecahan Masalah Sistematis. Jurnal Kreasi. 2015. Vol. XV No. 1.halaman 28-35. 
Sugesti, Fitri Era. Efektivitas Pembelajaran Statistika Kelas IX SMP Melalui Model Pembelajaran Kooperatif. Jurnal e-DuMath. 2015. Vol 2 No. 1. halaman: 78-85. 